\title{
Peles e Vidas Transformadas em Asfalto: Inquirições Ético-políticas de uma Barbárie
}

\author{
Lazaro Batista ${ }^{1}$ \\ Luis Antonio dos Santos Baptista ${ }^{2}$ \\ ${ }^{1}$ Universidade Federal de Roraima, RR, Brasil. \\ ${ }^{2}$ Universidade Federal Fluminense, RJ, Brasil. \\ Leonardo de Nardin ${ }^{3}$ \\ ${ }^{3}$ Universidade Federal de Roraima, RR, Brasil.
}

Resumo: $\mathrm{o}$ texto que compõe este ensaio aponta algumas passagens e relações entre a ditadura civil-militar brasileira e a constituição do estado de Roraima e da cidade de Boa Vista, sua capital. Para isso, parte do relato de um velho personagem desses eventos, remetendo-se, dentre outras coisas, ao incremento de fluxos migratórios, à extração predatória, à censura contra pessoas e, especialmente, ao contato genocida do homem branco com indígenas yanomami e wamiri-atroari na construção de duas estradas federais que atravessam os territórios dessas comunidades tradicionais. Do ponto de vista teórico-epistemológico, busca-se, com a Psicologia e suas diferentes interlocuções, um esforço aproximativo com tais histórias, as formas de contá-las e as diferentes políticas que podem sustentar nossa escuta do narrado. Situa-se, dessa maneira, como empreendimento ético-político duplamente implicado. Primeiro, esboçando as razões, instituições e práticas que tornaram possíveis a existência de tais acontecimentos. Segundo, alertando para o perigo de perpetuação ou repetição da barbárie no presente.

Palavras-chave: Ditadura, Genocídio, Índios, Narração, Precariedade e Luto.

\section{Skins and Lives Turned into Asphalt: Ethical-political Inquiries of Barbarism}

Abstract: The text that makes up this essay points to some excerpts and relations between the Brazilian civil-military dictatorship and the Roraima state's constitution as well as its capital, Boa Vista City. To do so, I start from the narrative of an old character of these events, referring, among other things, to the increment of migratory flows, to predatory extraction, to censorship against people and, especially, to the genocidal contact between white man and Yanomami and Wamiri-Atroari indigenous people, in the construction of two federal highways that go through the territories of these traditional communities. From the theoretical-epistemological point of view, it seeks, applying psychology and its different interlocutions, an approximate effort with such stories, the ways of counting them and the different policies that can sustain our listening to the narrated. It is placed, thus, as a double-implicated ethical-political undertaking. First, outlining the reasons, institutions, and practices that made possible the existence of such events. Second, alerting to the danger of perpetuation or repetition of barbarism in the present.

Keywords: Dictatorship, Genocide, Indians, Narration, Precariousness and Mourning. 


\title{
Pieles y Vidas Transformadas en Asfalto: Indagaciones Ético-políticas de una Barbarie
}

\begin{abstract}
Resumen: El texto que compone este ensayo apunta algunos pasajes y relaciones entre la dictadura civil-militar brasileña y la constitución del estado de Roraima y de la ciudad de Boa Vista, su capital. Para ello, parte del relato de un viejo personaje de esos eventos, que se remite, entre otras cosas, al incremento de flujos migratorios, a la extracción predatoria, a la censura contra las personas y, especialmente, al contacto genocida del hombre blanco con indígenas yanomami y wamiri-atroari en la construcción de dos carreteras federales que atraviesan los territorios de esas comunidades tradicionales. Desde el punto de vista teórico-epistemológico, se busca, con la psicología y sus diferentes interlocuciones, un esfuerzo aproximado con tales historias, las formas de contarlas y las diferentes políticas que pueden sostener nuestra escucha de lo que es narrado. Se sitúa, de esa manera, como emprendimiento ético-político doblemente implicado. Primero, demostrando las razones, instituciones y prácticas que hicieron posible la existencia de tales acontecimientos. Segundo, alertando sobre el peligro de perpetuación o repetición de la barbarie en el presente.
\end{abstract}

Palabras clave: Dictadura, Genocidio, Indios, Narración, Precariedad, Luto.

Ruídos trêmulos saem do corpo de um senhor raquítico, beirando os noventa anos, pele branca e muito enrugada. Fala um português compreensível, mas traz também restos de sotaque que denunciam sua origem estrangeira. Quase surdo em virtude da quantidade de vezes que teve de ser medicado para combater a febre amarela, ele tem histórias para contar. Narra penosamente o passado recente de massacre e extermínio presenciado sob o solo fértil de uma cidade na Amazônia brasileira. Nas imagens, memórias e testemunhos de sua narração, é possível sentir a ebulição causada pelas transformações sociais, políticas e econômicas experimentadas pela capital do estado de Roraima na segunda metade do século $\mathrm{XX}^{1}$. São imagens que nos provocam alvoroço. Um alvoroço de ira, mas também de medo. Fazem tremer e despencar sobre nossas cabeças um céu de novidades, transformações e modernizações, vertendo horror e barbárie contra todos que se opunham à sua força. Imagens de peles humanas transformadas em asfalto; metamorfose necessária para a construção de uma cidade da ordem e progresso.

Palavras quase inaudíveis e inquietantes saem de sua boca, ansiosas por alcançar a cidade, forjar imagens dela e com ela. Tornam-se navalhas afiadas em um passado recente que ainda produz cortes no presente e conserva feridas ainda não cicatrizadas. Um corte profundo e gangrenoso que atende pelo nome de ditadura civil-militar. Palavra não tão distante, num momento em que outros golpes são desferidos, transvestidos de estado democrático de direito.

Diz a voz trêmula que ditadura foi, e é, a repressão das manifestações, do pensamento, da mídia, da $\mathrm{TV}$, jornais, das revistas, rádios, música, pintura, fotografia... É o favorecimento de interesses de amigos, parentes e correligionários. É para alguns tudo e para outros, o que se acha conveniente. É a diminuição gradual das liberdades, também a exaltação de uma democracia aparente. São as tentativas de legitimação do poder, sob o pretexto, por exemplo de preservar a muito divulgada segurança nacional. É a muita publi-

\footnotetext{
${ }^{1}$ Em 15 de março de 2018, o Centro de Ciências Humanas da Universidade Federal de Roraima organizou o Colóquio "54 anos depois do golpe: atrocidades contra os povos da Amazônia". Dentre os convidados, estavam Carlos Zaquini, missionário italiano que atua junto a grupos indígenas de Roraima desde a década de 1970. Em sua fala, Zaquini resolveu fazer um apanhado de como a Ditadura influenciou na constituição do estado e da cidade de Boa Vista, remetendo ao incremento de fluxos migratórios, à extração predatória, à censura contra pessoas, ao contato genocida dos brancos com indígenas. Tomando como ponto de partida a transcrição e reprodução - devidamente autorizada - da fala proferida por ele, o texto que compõe este ensaio busca aprofundar e referenciar algumas dessas passagens sobre a história recente do país, do estado de Roraima e de sua capital, Boa Vista.
} 
cidade dos "sucessos econômicos". Normalmente, sucessos de amigos do poder ou de determinado grupo. Quando não, a manipulação dos números do "milagre econômico". É a crença retórica de modernização conservadora que sustenta uma aliança entre elites agrárias, setores empresariais nacionais e multinacionais e setores da sociedade civil. É o temor do espantalho do totalitarismo comunista, colocado como o perigo maior. É o incentivo à ocupação da Amazônia, afirma a voz que não se deixou abater pelas mazelas da floresta e do tempo.

Ao longo dos 21 anos do Regime Militar, em Roraima, se sucederam vários governadores escolhidos entre os coronéis da aeronáutica. Sua presença se mostrou intensa a partir de 1969, quando, motivado pela visita de Fidel Castro à Guiana, o Governo brasileiro determinou o envio de tropas para defender o território da possível invasão comunista ${ }^{2}$. De repente, cerca de dois a três mil homens chegaram porque Fidel Castro tinha visitado o país vizinho que tinha acabado de obter a independência. A defesa das fronteiras do território foi o pretexto para transformar a capital roraimense em laboratório das inciativas militares. Boa Vista viu o caos causado por falta de gêneros de todo tipo, de pregos e parafusos a colchões e alimentos. Ainda não havia estradas que ligassem Roraima a outros estados, então, dependia-se exclusivamente dos suprimentos transportados por barco ou avião. Esse relativo caos urbano, por certo decorreu do considerável aumento populacional do período, com intensas ondas migratórias que fizeram a população de Boa Vista passar de pouco mais de 28 mil pessoas em 1960 para mais de 40 mil em 1970 (IBGE, 1970). Números elevados, mas nada comparados ao tama- nho da violência praticada na construção de duas rodovias: a BR-174 e BR-210!

No caso da primeira estrada, construí-la significou passar, literalmente, por cima do povo indígena waimi-atroari. A obra inicialmente ficou a cargo do Departamento Nacional de Estrada e Rodagens (DNER) e do Departamento Estadual de Rodagens do Estado do Amazonas (DER-AM), no ano 1968. Para ser realizada, teria que cruzar a região habitada pelos índios. Povo temido pelas notícias de sua ferocidade e de sua posição contrária à presença de estranhos em seus domínios territoriais. Antes do início dos trabalhos de desmatamento da estrada empreendeu-se contatos para tentar tornar os índios "mansos" e prontos inclusive para participarem, como mão de obra, nos serviços de desmatamento (Carvalho, 1982). Coube ao padre italiano Giovanni Calleri, membro atuante da Prelazia da Consolata em Roraima, a missão. O clérigo, quase sem nenhuma experiência de incursão em tribos, extremamente preconceituoso em relação ao modo de vida indígena e agressivo no trato com eles, acabou sendo morto, junto com mais nove integrantes da expedição. Restou apenas um sobrevivente, que teria percebido o clima de animosidade que o padre havia instaurado e fugido para a mata. Foi graças a ele que se soube do ocorrido e tornou-se possível identificar os restos mortais dos demais. Depois desse episódio, outras campanhas de contato foram rechaçadas pelos índios, com outros ataques ${ }^{4}$.

Já no início da década de 1970, os trabalhos da construção da Rodovia foram reiniciados, com a transferência da responsabilidade da obra do DER-AM para o $2^{\circ}$ Grupamento de Engenharia e Construção - $6^{\circ}$ Batalhão de Construção do Exército

\footnotetext{
${ }^{2}$ O Regime Militar e sua Doutrina da Segurança Nacional tomavam a Região Amazônica e suas fronteiras como elementos de primeira ordem. No início incipiente, essa política se ampliou por meio do Decreto-Lei no 63.104, de 15 de agosto de 1968, que priorizava a "efetiva ocupação e povoamento orientados da Região Amazônica, notadamente quanto aos espaços vazios e zonas de fronteiras", dentre as quais situava a cidade de Boa Vista e o Território de Roraima. Um dos pontos altos disso, seria a visita do Presidente da República, o Marechal Artur da Costa e Silva, em 1969 para inauguração do Palácio 31 de março - sede do governo - e acompanhamento da série de obras pelas quais passava Boa Vista. Como apontam Souza e Vieira (2009), essa visão geopolítica e ideológica resultou em um maior apoio financeiro, controle sobre a administração territorial e vigilância por parte do governo militar sobre o Território. Dentre as ações, poderíamos apontar a construção de estradas, obras de infraestrutura e o fortalecimento da presença militar na região, por meio da criação dos Batalhões de Fronteira. Em especial, o Comando de Fronteira de Roraima (CFR), criado em 23 de maio de 1969, com sede em Boa Vista.
}

${ }^{3}$ A Rodovia BR-174 liga a Região Norte brasileira à Venezuela, atravessando o estado de Roraima. Já a BR-210, também conhecida como Perimetral Norte, tem quase três mil quilômetros de extensão e deveria ligar o Atlântico (Macapá) à Colômbia. Parte dela atravessa a Região Sul de Roraima. Ambas foram idealizadas no período da Ditadura como parte da corrida desenvolvimentista dos militares e de integração do Extremo Norte ao restante do país.

${ }^{4}$ Segundo Carvalho (1982), mais de 60 funcionários da Funai e do Serviço de Proteção ao Índio morreram nas tentativas de fazer amizade com os índios Waimiri Atroari, procurando nunca tomar medidas repressivas contra aquele povo. 
Brasileiro. É nesse instante que a barbárie veste farda, ordenando-se genocida:

[...] o General Comandante, nos fez ciente de que já mandara para as frentes de trabalho da estrada, brigadas de soldados do Exército armados, prontos para "defenderem a qualquer custo, a continuidade dos serviços de desmatamento e terraplanagem da estrada Manaus-Boa Vista". Aquela notícia, dada pelo General, deixou-nos perplexos e procuramos argumentar junto ao Comandante que naquele momento não era oportuno a continuidade do trabalho da estrada e muito menos prudente o envio ao local de tropas do Exército "prontos para defenderem, a qualquer custo, a continuidade dos trabalhos"; como afirmara. O General comandante, diante de outros oficiais presentes naquela reunião, respondendo as nossas ponderações afirmou "A Estrada (BR-174) tem que ficar pronta, mesmo que para isto tenhamos que abrir fogo contra esses índios assassinos. Eles já nos desafiaram muito e estão atrapalhando nossos trabalhos. Temos um compromisso de entregar esta estrada pronta. E não vai ser um grupo de índios assassinos que vai impedir o prosseguimento da obra (Carvalho, 1982, p. 74).

A política oficial do Regime Militar, nas palavras dos militares mais importantes do estado torna-se clara: a rica e inexplorada Amazônia, patrimônio nacional, oferecia todas as condições para alavancar o desenvolvimento econômico do país, de modo que qualquer empecilho que dificultasse isso deveria ser removido ${ }^{5}$. No país do golpe, a ameaça indígena o torna inimigo da nação, guerrilheiro que deve se render ou ser combatido até a morte pelo "teatro de operações" das Forças Armadas ${ }^{6}$. A rendição índia não veio. O genocídio se fez!

Ouvi falar que o sangue deu no meio da canela. Tanto assim que depois de um ano eu fiz a união das frentes norte e sul e não vi índios. Vi porcos do mato, macaco, cobras, tudo isso eu vi, mas índios mesmo... nem viva alma. E tem mais: a qualquer máquina que trabalhava na estrada em área indígena, o BEC dava uma cobertura enorme em armas. O Exército ficava ali, ao lado, enquanto o pessoal ia trabalhando. Isso todos sabem (Sabatini, 1998, p. 107) ${ }^{7}$.

Como consequência da incursão militar, apenas uma décima parte dos índios, ou um pouco mais, sobreviveu. De acordo com o Comitê da Verdade do Amazonas (2012), a população que era, até o início da década de 1970, de aproximadamente 3.000 índios, sem notícias sobre alguma grave epidemia, foi estimava em menos de 1.000 membros em meados de 1974. Já em 1983, esse número reduziu-se para apenas 332 pessoas sobreviventes, dos quais 216 eram crianças ou jovens com menos de 20 anos. Em nome do pretenso desenvolvimento econômico, algo em torno de dois mil e setecentos índios foram dizimados nas mãos dos soldados brasileiros. As histórias que se contam sobre aquela passagem são bastante tenebrosas, mas quase ignoradas pela história oficial do país, do estado, da cidade. Os milhares de índios sequer constam da relação de mortes praticadas pela Ditadura. São corpos e histórias sumidos, como se nunca tivessem existido.

Os relatos do velho senhor, com sua voz mansa contam também que não só com tanques e tiros de arma de fogo se faz um genocídio. Junto a ele, as pala-

\footnotetext{
${ }^{5}$ Em matéria veiculada pelo Jornal A Crítica, em março de 1975 (Anônimo), o então governador do Território de Roraima, Coronel Fernando Ramos Pereira afirmou que "uma terra tão rica quanto esta não se pode dar ao luxo de deixar meia dúzia de tribos de índios entravar seu desenvolvimento" (sem paginação).

${ }^{6}$ Dentre os documentos recolhidos pelo Relatório Estadual do Comitê da Verdade do Estado do Amazonas (2012), consta cópia de um panfleto jogado pelos militares sobre as áreas ocupadas pelos indígenas. Escrito em verso, o texto recomendava a rendição dos indígenas e assegurava o perdão àqueles que apresentassem o panfleto ao Teatro da Operação Atroaris. Segue integra do texto, transcrito: “Guerrilheiro, Lê com atenção esta 'mensagem' / Guarda este panfleto com cuidado / Ele é o teu passaporte para a vida / Estás cercado / Teus momentos estão contados / Vê na operação esboçada que teu fim / Está próximo! / Teus companheiros estão morrendo / Tu mesmo estás ferido / Os soldados brasileiros - teus irmãos / Estão cada vez mais próximos / A aviação te bombardeia sem cessar / Olha a bandeira de teu país / És brasileiro - lembra-te disto / Reflete, pensa bem - o verdadeiro inimigo / Pode estar a teu lado: repudia-o, aprisiona-o, mata-o / Irmão - rende-te / Teu passaporte: esta mensagem / Tua recompensa: a vida / Teu futuro: perdão. Do comandante do teatro de operações" (p. 45).
}

${ }^{7}$ O trecho está presente em Sabatini (1998, p. 107) e é parte da entrevista concedida por Rainor Abensur de Sousa, topógrafo que trabalhou na construção da BR-174. Num contexto mais amplo, o entrevistado aponta que, frente à resistência dos índios, o governo ordenou a retirada temporária de todos os trabalhadores da obra, deixando apenas militares na região. 
vras recolhidas por outros missionários ajudam a dimensionar outras barbáries, praticadas com usos mais sofisticados:

O pessoal das aldeias do Norte ainda estava a caminho. A festa já estava começando com muita gente reunida. Pelo meio dia um ronco de avião se aproxima. O pessoal sai das malocas para ver. A criançada se concentra no pátio. $\mathrm{O}$ avião derramou um pó e todos morreram, menos um. O tuxaua Comprido estava a caminho. Vinha do norte com a sua gente. Chegando perto do pátio estranharam o silêncio. Aldeia em festa sempre está cheia de algazarra. Ao se aproximarem encontraram todos mortos, menos um. Morreram sem sinal de violência no corpo. Dentro da maloca, nos girais, grande quantidade de carne moqueada, mostrando que tudo estava preparado para acolher muita gente. O sobrevivente só se recordava do barulho do avião passando por cima da aldeia e do pó que caia. Os Kiña forneceram uma relação de 33 parentes mortos neste massacre (Schwade, 2011).

Sutileza ainda mais mortal se deu na outra obra! No caso da construção da BR-210, índios ianomâmis apareceram nus na frente dos tratores. Apenas o contato com a carne ou objetos dos homens brancos foi necessário para dizimar aldeia após aldeia. O contato inicialmente amistoso, a troca de objetos, a sedução pelas mercadorias, escondiam dos índios a crueldade de arrancar o "chão da floresta". Ao mesmo tempo, o sarampo, a gripe, a febre amarela, contaminavam os nativos. Da pior forma possível, aprendemos que não apenas as máquinas matam com suas fumaças. Também os imundos corpos poluídos pelas "fumaças de epidemia” que costumam acompanhar os brancos ${ }^{8}$.

Os que sobreviveram no primeiro trecho da obra, ficavam andando para frente e para trás ao longo da estrada, pedindo comida, roupa, redes. Dias antes não precisavam disso. Mas, de repente, passaram de pessoas sadias, altivas, autônomas, herdeiras de uma cultura muito rica a miseráveis adoentados, famintos, pedintes. Naturalmente, foram as doenças que foram introduzidas sem que o Governo ou a Fundação Nacional do Índio (Funai) tomasse medidas eficientes para vaciná-los ou curá-los. A consequência foram epidemias que se seguiam uma após a outra.

Contam as palavras do raquítico senhor que não foram poucas as mortes ao longo dos primeiros cem quilômetros da BR-210 no território ianomâmi: das 15 aldeias sem contato ou com pouquíssimo contato na região onde se deu o início da construção da rodovia, sobraram pouco mais de 50 pessoas vivas depois que a obra se encerrou. Muitos mortos sem sequer compreender o que se passava. Muitos outros, sem que sequer lhes fosse ofertado qualquer tipo de assistência. Tantos outros sem que, ao menos, fosse possível a contagem para saber quantos eram e que costumes tinham.

As palavras claudicantes do velho narrador tremem um pouco mais, ao se deparar com o regozijo de muitos que admiram e bendizem os tiros, tratores e ataques químicos. Incólumes às palavras, esses ouvidos dizem que foram valorosos os serviços prestados à pátria. Afirmam a campanha de construção das rodovias como desempenho primoroso que ajudou a desenvolver o estado e fazer a bonita cidade ligar-se ao restante do país. Ode e perpetuação do extermínio praticado pela briosa instituição que, nas palavras recentes de um dos seus mais proeminentes senhores, "possui uma trajetória percorrida com desenvoltura,

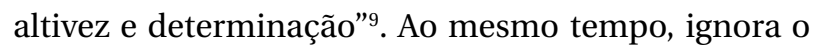
sangue e vida daqueles milhares de mortos, a voz cansada do velho narrador, as repercussões desse passado na atualidade.

A narração rouca do velho missionário recobra tais genocídios no presente da cidade, do estado, do país. Demonstra urgência de restituírem a memória de mortos que se foram como se não tivessem exis-

\footnotetext{
${ }^{8}$ De acordo com Kopenawa e Albert (2015), as "fumaças de epidemia" são transferidas pelos espíritos que "costumam acompanhar os brancos por onde forem, porque estes são seus sogros. Mantêm os olhos fixos neles e se deslocam seguindo seus rastros. É assim que nos conseguem encontrar na floresta. São seres maléficos ávidos por gordura humana. Apenas os xamãs podem vê-los. Os xapiri tentam expulsá-los assim que se aproximam de nós. Porém, quando não conseguem afugentá-los, os xawari instalam suas redes nas nossas casas e vão nos devorando à vontade, sem pressa. Não matam todos de uma só vez, não. Comem primeiro um grupo de gente, e voltam em seguida para devorar uma parte dos sobreviventes. Caso alguns homens e mulheres consigam escapar deles, mais tarde irão atacar seus filhos. É assim que esses seres maléficos vão aos poucos esvaziando a floresta de seus habitantes" ( $p$. 309).

${ }^{9}$ Fala de Silvio José de Melo Brito, então major e subcomandante do $6{ }^{\circ}$ BEC (2016), em matéria de julho de 2016, do Jornal Folha de Boa Vista, alusiva ao quadragésimo oitavo aniversário de fundação do Batalhão.
} 
tido, deslocando a história do lugar como usualmente contada. O narrador sugere que no passado algo ainda acontece, estaria inacabado a espera de outros narradores para o prosseguimento das suas tramas. Para o homem que testemunhou as barbáries do progresso na floresta, a conclusividade do passado, assim como a inscrita nas utopias do futuro são letais. Apesar de tanto sangue e morte, o que há ainda por contar? Como restituir, do ponto de vista da ciência psicológica, a escamoteação dessas vidas?

\section{Fazer rachar o asfalto: psicologia e implicações ético-políticas do narrar}

De saída, é importante pensarmos a posição que os modos de narrar ocupam, que funções exercem e de que modo se relacionam com os processos de violência, exclusão e morte supracitados. Para isso, devemos ter em conta que todo e qualquer modo de narrar implica mundos, conduz lutas e investe programas políticos diferentes. A esse respeito, nas suas Teses sobre o conceito de história, Walter Benjamin defende que independente das pretensas suposições de neutralidade que algumas tendências teóricas possam tentar sustentar, aquele que conta a história possui necessariamente um posicionamento. $\mathrm{Ou}$ seja, mesmo sob a crença em uma exatidão científica, "delineia-se uma história, uma narração que obedece a interesses precisos" como bem coloca Gagnebin (2016, p. 40).

Esse modo de narrar, que Benjamin qualifica como "comemorativa", alinhada aos poderes estabelecidos, recolhe bens culturais dos eventos na política e na história que, concatenados numa linearidade lógica e temporal, são tomados como confirmadores da ideia de progresso através da liberdade política e da racionalidade científica. Essa historiografia é sobretudo asséptica e sacralizada, pois ela exclui eventos que são a antítese, ou coloquem em questão, as promessas do progresso.

Tais promessas ignoram, por exemplo, o fato de que os bens culturais, os governos, leis, códigos, princípios, instituições, ideias, ideais, formas de sociabilidade existentes, enfim, tudo aquilo que podemos colocar sob o nome de cultura ou de civilização, e de que os homens se orgulham por supostamente os colocarem num patamar acima da natureza (Freud, 2006), nascem na violência e se prolongam a repetindo. Enfim, todo processo de transmissão da cultura é, desse modo, marcado e motivado pela barbárie a ele subjacente: "Nunca houve um monumento da cultura que não fosse também um monumento de barbárie" (Benjamin, 1987, p. 225). Ou ainda, de forma cheia de sentido, conforme escreve Deleuze ao citar Georges Bataille: "como regra geral, o carrasco não emprega a linguagem da violência que ele exerce em nome de um poder estabelecido, emprega a do poder, que aparentemente o desculpa, o justifica e fundamenta sua posição" (Deleuze, 2009, p. 19).

No entanto, as mais diferentes modalidades de violência induzidas sobre determinados grupos humanos são excluídas das narrativas dos poderes estabelecidos que preconizam segurança e estabilidade. Por isso, Benjamin chama a atenção para a necessidade de compor novas formas de narrativas contra a ordem e estabilidade preconizada pelos partidários da história comemorativa. Com o filósofo materialista, portanto, compreendemos que conjuntamente às pretensões de neutralidade e objetividade, encontramos relações de poder e de dominação que devem ser alvo de crítica e resistência.

Para tanto, o pensador alemão vê naquilo que denomina como "classe combatente e oprimida" a potência necessária para a libertação, tanto no presente quanto no passado: os ciclos de esperanças no progresso aos quais estamos agrilhoados e que sempre foram violento e destrutivo para uma parcela da população. Isso exige àqueles que tem a prerrogativa da escuta e do compartilhamento da narrativa um deslocamos em relação a essas formações epistemológicas. Deslocamento que nos encaminhe para possibilidade de pensar e praticar uma Psicologia compromissada com as tantas vidas nas quais esse sistema dominante resvala de forma violenta. Ou seja, tornar urgente e necessária uma ciência psi com metas éticas e políticas explícitas que se constitua nas antípodas daquela história comemorativa, sobre a qual não possa refletir senão com um "assombro insustentável". Assombro que nos conduza a uma atitude ética de explicitar tais incidentes históricos e nos indagar sobre os jogos de poder e suas linhas de fuga (Lemos, \& Galindo, 2013).

Assim pensada, essa ética veria nas imagens de um suposto progresso urbano mais do que os auspícios do desenvolvimento e integração nacional de uma cidade ao restante do país. Enxergaria nas imagens de genocídio índio não o progresso professado pelas grandes sínteses doutrinárias, mas uma sucessão de eventos repletos de morte e destruição. 
Nesse sentido, nos aproximamos também do projeto de Foucault (2012) de restituir, na análise, a intensidade que a vida conceituada como infame tem no seu momento de encontro com o poder: tomando tais mortes a partir da aridez do relato e intentado problematizar algumas das instituições ou práticas políticas a que elas se referiam. Trata-se, então, de efetuar com a Psicologia e suas diferentes interlocuções epistemológicas um esforço aproximativo com tais histórias que tente, ao menos, esboçar as razões pelas quais "se quis impedir com tanto zelo os pobres espíritos de passearem pelas estradas desconhecidas" (Foucault, 2012, p. 200-1).

Ao invés de investir em uma narrativa comprometida com a produção de nexos causais entre eventos que possam testemunhar e comemorar a marcha humana rumo ao progresso, esse outro entendimento nos exige um conceito de história que a escove $a$ contrapelo e que permita o combate e a crítica aos perigos subjacentes e reincidentes a ideia de marcha. Um perigo duplo, segundo Benjamin. Por um lado, o do presente repetir a barbárie do passado: "entregar-se às classes dominantes, como seu instrumento" (p. 243). Por outro lado, o perigo dos dominantes continuarem vencendo, possibilidade aterradora conquanto signifique que tais mortos não poderão encontrar sossego ou descanso.

Além disso, ainda do ponto de vista da Psicologia como ciência e profissão e daquilo que podemos empreender no combate às iniquidades, à exclusão social, às práticas de apagamento e extermínio de povos e comunidades tradicionais, a apropriação dessas formas de contar assim compromissadas nos coloca na possibilidade de pensar essas existências não apenas em oposição às normas sob as quais algumas vidas se desenvolvem, mas como positivas nelas mesmas. Quando Benjamin sugere que nos coloquemos do lado das classes combatentes, isso não deve significar que devemos estabelecer uma verdade e uma identidade sobre essa classe, e nos obrigar a viver de acordo com essa identidade. Como bem coloca Gagnebin (2006), o testemunho e a transmissão do que fora feito com tais vidas têm, nesses termos, o objetivo justamente de romper com as divisões simples (algoz/vítima, inocente/culpado, fora da lei/Estado oficial) para permitir novos modos de narrar os equívocos nelas implicados. Dessa maneira, efetuar tal crítica torna possível não continuarmos a repetir indefinidamente o passado, mas questioná-lo, forçá-lo a se abrir, como rasgo que aponta não apenas as passagens de um pretérito soterrado, mas junto aquilo que dele é regurgitado no presente.

Algo nalguma medida semelhante ao apontado por Didi-Huberman (2013) no ensaio Cascas, ao narrar seu passeio pelo campo de concentração de Auschwitz-Birknau, localizado em meio a uma floresta de bétulas, na Polônia. Nesse texto, ele propõe indicar as reminiscências do extermínio nazista na vegetação e ruínas do campo, a despeito das tentativas de se produzir uma memória oficial do holocausto - em partes - pela vinculação de imagens pacificadas, polidas ou esteticamente "tratadas". Dentre as indicações dessa memória que insiste em permanecer viva, mesmo em face de todo o empreendimento mortífero que a rodeia, há duas que podemos pôr em destaque. Primeiro, sua observação da exuberância das flores como resultado da hecatombe humana nazista. Ou seja, o substrato que alimentam as flores são as próprias cinzas dos milhares de vidas incineradas naquele chão. Segundo, contra o projeto de pacificação das imagens de horror ou as tentativas de representar aquilo tudo como obra do passado, diz Didi-Huberman que ocasionalmente o chão, literalmente, se abre e fazer emergir "cascas da história" - pedaços de ossos, talheres, pratos, rachaduras nas paredes, cacos de copos, tigelas etc. - lançados à superfície como vestígios das chacinas cometidas e da miserável riqueza ainda viva daqueles que foram assassinados. Que outros pedaços de história desprendem-se e emergem dos refugos narrativos que nos chegam pela voz rouca do velho missionário? Como explicar a possibilidade de assassinato praticado contra índios no Extremo Norte do Brasil?

\section{Explicar o injustificável}

Aproximamo-nos em muito das análises efetuadas por dois intelectuais contemporâneos para encaminhar respostas às questões acima. O primeiro deles, o filósofo camaronês Mbembe (2016), nos indica tais processos efetuados sob essas comunidades tradicionais como perpetuadores de um regime de soberania que se sustenta a partir de uma peculiar interpretação dessas vidas como em desigualdade jurídica em relação aos homens brancos. Em face desse suposto desnível hierárquico, sob tais povos e comunidades agem dispositivos em que o exercício da soberania pode se transvestir de estado de exceção. Isso, ao mesmo 
tempo em que reivindica que sua intervenção é de humanização sobre supostos selvagens.

Dessa maneira, o assassinato dessas pessoas se torna mais um elemento de luta contra a natureza do que a morte praticada sob outra vida humana. Quando muito, a morte dessa determinada raça passa a ser vista como mais uma fronteira demarcada na disputa do homem civilizado contra a natureza selvagem, tal qual ocupar e demarcar suas terras com sinais religiosos ou políticos.

No mesmo contexto, as colônias são semelhantes às fronteiras. Elas são habitadas por "selvagens". As colônias não são organizadas de forma estatal e não criaram um mundo humano. Seus exércitos não formam uma entidade distinta, e suas guerras não são guerras entre exércitos regulares. Não implicam a mobilização de sujeitos soberanos (cidadãos) que se respeitam mutuamente, mesmo que inimigos. Não estabelecem distinção entre combatentes e não combatentes ou, novamente, "inimigo" e "criminoso". Assim, é impossível firmar a paz com eles. Em suma, as colônias são zonas em que guerra e desordem, figuras internas e externas da política, ficam lado a lado ou se alternam. Como tal, as colônias são o local por excelência em que os controles e as garantias de ordem judicial podem ser suspensos - a zona em que a violência do estado de exceção supostamente opera a serviço da "civilização" (Mbembe, 2016, p. 133).

A produção dessa distinção de direitos, portanto, se tornaria registro de um racismo de estado que inscreve sobre um terreno um novo conjunto de relações sociais: demarcando e hierarquizando lugares, classificando pessoas de acordo com diferentes categorias, monopolizando recursos, produzindo um amplo imaginário cultural e efetuando, por esses diversos marcadores, mortes de diferente matizes. Produção de subjetividades que "deram sentido à instituição de direitos diferentes, para diferentes categorias de pessoas, para fins diferentes no interior de um mesmo espaço" (p. 136). Enfim, surge aí uma modalidade de soberania que se notabiliza pela capacidade de definir aqueles que importam e os que não importam; quem é "descartável” e quem não é.

Parelho a essa discussão, temos os estudos de Butler (2015) a respeito dos modos pelos quais uma cultura se relaciona, ética e afetivamente, com a distribuição desigual de precariedade. Tal discussão nos interessa na medida que suscita a problemática das condições que tornam possível qualificar ou reconhecer uma vida como tal. Butler, pensando a herança de Michel Foucault, estabelece que os termos que possibilitam um reconhecimento são fornecidos por um regime de verdade. Entende ela que, primeiro, esses termos são "quadros" nos quais estão inscritos os limites do reconhecimento, ou seja, esses quadros dizem que formas podem ou não, ser reconhecíveis.

Esses quadros de reconhecimento funcionam ou fazem funcionar coisas à medida que são compartilhados - se queremos que a vida tenha sentido para nós, será preciso que a vida também tenha sentido para o outro. Isso significa dizer que os condicionantes responsáveis pelo reconhecimento de uma vida enquanto vida, derivam das relações sociais, mas também significa que esses modos de reconhecimento assumem a forma e mudam ao sabor das transformações nas relações sociais.

Butler (2015) vai mais além e afirma que esses quadros de reconhecimento possíveis de serem constituídos a partir da ontologia social, só o podem na condição de estarem "politicamente saturados"; ou seja, de estarem prenhes de instituições, organizações e interpretações políticas que se desenvolvem variável e historicamente com a finalidade de investir as normas corretas e necessárias para tal reconhecimento. Isso significa dizer que os enquadramentos são operações politicamente induzidas a partir de uma normatividade.

Assim sendo, para ela os modos pelos quais se apreende uma vida como viva, qualificada, precária, passível ou não de luto, depende da correspondência do seu desenvolvimento com relação a uma normatividade: "A capacidade epistemológica de apreender uma vida é parcialmente dependente de que a vida seja produzida de acordo com normas que a caracterizam como uma vida ou, melhor dizendo, como parte da vida" (Butler, 2015, p. 16). A vida produzida em consonância com uma norma será passível de reconhecer e ser reconhecida como viva e digna de proteção, enquanto que a vida que não quer ou que não pode se adequar às normas, porque lhe falta as condições de possibilidade necessária para tal, não é passível, parcial ou em totalidade, de ser reconhecida como uma vida porque de partida ela é desqualificada como viva. 
Esses quadros e normas de reconhecimento se mostram de proporções enormes quando reconhecemos que eles oferecem as condições éticas e afetivas necessárias para a relação de aceitação de algumas vidas em condições que são de miséria, de violência e de morte. Por outro lado, se assim for, se as normas que temos prescrevem que algumas vidas são descartáveis, não passíveis de reconhecimento e por isso susceptíveis à violência politicamente induzida, eles também podem ser os instrumentos necessários para conduzir a crítica dos enquadramentos e a resistência às normas.

Portanto, as relações políticas e sociais tais como as temos (incluídas as relações de direito, de cidadania e de proteção da vida) são o fundamento que torna comunidades tradicionais e as formas de vida a elas vinculadas desqualificadas como vivas. Do mesmo modo, tornando-as mais suscetíveis à violência, à expropriação, à dominação, à miséria generalizada e à morte sem luto.

É, finalmente, nesse sentido que tal discussão pode nos servir para ratificar a necessidade de incluirmos em nossas obrigações éticas e políticas o compromisso com a condução de lutas capazes de forjar outros enquadramentos. Em especial, quadros que se afirmem responsáveis pela produção das condições necessárias para que essas vidas possam, por meio de um ato de reconhecimento propriamente dito, serem qualificadas com vidas vivíveis.

\section{Concluindo: por um presente que não repita o passado}

Da relação entre período militar e extermínio, nasce uma cidade transformada. Transformação que, do ponto de vista indígena, fabricou a morte de tudo aquilo que encontrava. São histórias dos dias em que máquinas e homens abriram os caminhos da cidade em direção ao restante do país (Diniz, 1998), mas também em direção à barbárie. Narrativas de acontecimentos que fizeram e fazem desmoronar o mundo que residia no meio da mata. Imagens do encontro com epidemias, ganância e motores que poluem com suas fumaças os olhos dos homens da cidade, o céu da floresta e a vida.

As experiências vividas por yanomami e waimiris ilustram o que se abateu sobre os povos indígenas da Amazônia quando se deu o encontro com os brancos, materializado em rodovias, hidrelétricas e outros ícones da modernização. Foi com a carne deles que se pagou a ligação do estado de Roraima, especialmente sua capital, ao resto do país. Para romper as fronteiras do acesso aos bens e consumo, esfolou-se a pele indígena, fazendo-a asfalto. Isso feito como projeto nacional, levado a cabo por empresários, mas incentivado e até mesmo suportado pelo governo militar brasileiro. Afinal, nunca é muito lembrar, esses acontecimentos compuseram o repertório de uma política de integração que, de um lado, afirmava a necessidade de proteção nacional; enquanto que, noutra via, passava a ver qualquer opositor como inimigo da nação. É nesse sentido que a política genocida adotada contra os índios precisa ser vista, portanto: como parte de um dispositivo de repressões praticadas de tantos outros modos bárbaros no mesmo período.

A fúria contra os milhares mortos certamente nos fala de "homem-máquina como trator" (Kopenawa, \& Albert, 2015) que ignoram o peso da história. Ainda hoje muitos deles parecem não suspeitar que suas ações implicam em fazer desabar sobre si mesmos o ordenamento do mundo. Como máquinas, não enxergam o indelével e intempestivo barulho que vem da floresta, ainda viva, mesmo depois de asfaltada, intoxicada, remexida.

O corpo em frangalho do velho estrangeiro, no entanto, expurga e estraçalha a louvação dessa história. Suas vacilantes palavras instauram rachadura nessa estrutura. Provocam o olhar a enxergar no verde camuflado imagens que não mais podem desvencilhá-lo das formas elogiosas com que se perpetuou naquele lugar um mecanismo de extermínio para a fabricação de uma cidade e de um projeto político. Tornam-se emblema de um lugar feito para homens-trator que tornaram o existir desses povos sufocados com fumaça, óleo e pólvora.

A cidade desses homens-trator continua a crescer, vigorosa por dominar mais alguns povos, subjugando-os. A sombra daqueles dias narrados pelo velho missionário aparece cada vez mais próxima no horizonte daqueles que, por sorte ou sina, não sucumbiram à ditadura de outros tempos. Os homens sujos de verde retornam ao poder, de maneira que não poderá haver paz aos que insistem em não se subjugar: as primeiras iniciativas do recém-empossado presidente da república explicitam seu alinhamento contrário aos modos de vida dos povos tradicionais. Duas ações recentes indicam isso claramente. Primeiro, ao destinar ao Ministério da Agricultura - comandado por representantes do 
agronegócio - as atribuições de identificação, delimitação e demarcação de terras indígenas no país (Medida provisória no $870 / 2019$ ).

Essa medida possivelmente significará ainda mais acirramento e violência na relação entre índios e brancos, em franco desfavor dos primeiros. No caso de Roraima, estas conjecturas tornam-se ainda mais preocupantes, ao considerarmos duas nuances. A primeira é o fato de que o estado é o que dispõe das maiores porções de terra demarcadas, com $3 / 4$ de todo o território composto por reservas indígenas. A segunda, a particularidade de se especular existirem imensas reservas minerais no solo desses territórios, a maioria ainda completamente intocada, o que aumenta o interesse econômico de exploração agropecuária e mineral da região.

Segundo a recente decisão de levar adiante a interligação energética de Roraima ao restante do país, através da construção de uma linha elétrica que atravessará a reserva dos índios waimiri-atroari (Resolução no 1, 2019). Alçado ao status de obra fundamental à defesa da soberania e integridade nacional, o chamado Linhão de Tucuruí terá sua cons- trução acelerada, inclusive "cortando etapas" do licenciamento ambiental. Como se isso já não fosse grave o bastante, promete também produzir novos cortes na carne dos infames, ao retomar a máxima de outrora para sugerir como se dará o trato com os índios: "iremos por sempre consultá-los, mas obviamente o interesse da soberania nacional tem que ser imagino, acima de determinadas questões que venham a entravar esse processo" ${ }^{10}$.

São palavras que parecem retiradas do passado, repetindo suas justificativas e prometendo suas mortes e seu dissenso. Quiçá nesses "novos-velhos" tempos a ferrugem asquerosa de suas máquinas não tarde em consumir penosamente seus mitos e asseclas. Quiçá, em cada respingo de verde-oliva, possamos enxergar o peculiar cheiro e gosto ferroso do aço que consome os corpos que não aceitam suas prescrições e normas. Quiçá o frêmito que conduziu a narração do que se passou naqueles dias nos faça reconhecer e lutar contra mais essa ameaça à nossa já claudicante diversidade. Nesse dia, apesar de tudo, o sussurro proferido pelos homens da mata ecoará ainda mais indelével, ainda mais intempestivo, ainda mais vivo.

\section{Referências}

Anônimo. (1975, abr.). Atração atroari é desafio à FUNAI. Jornal A Crítica.

Benjamin, W. (1987). Teses sobre o conceito de história. In: W. Benjamin, Obras escolhidas: magia e técnica, arte e política (3a ed., pp. 222-232). São Paulo, SP: Brasiliense.

Butler, J. (2015). Quadros de guerra: Quando a vida é passível de luto? Rio de Janeiro, RJ: Civilização Brasileiro.

Carvalho, J. P. F. (1982). Waimiri Atroari a história que ainda não foi contada. Brasília, DF: o autor. Recuperado de http://www.antropologias.org/files/downloads/2012/03/Waimiri-Atroari-Jos\%C3\%A9-Porf\%C3\%ADrio.pdf

Comitê da Verdade do Amazonas - CVA. (2012). $1^{\circ}$ relatório do comitê estadual da verdade: O genocídio do povo Waimiri-Atroari. Manaus, AM: o autor. Recuperado de https://www.marxists.org/portugues/tematica/livros/ diversos/genocidio.pdf

Decreto $\mathrm{n}^{\circ}$ 63.104, de 15 de agosto de 1968. Dispõe sôbre a política do governo federal relativo à efetiva ocupação e povoamento orientados da região Amazônica, notadamente quanto aos espaços vazios e zonas de fronteiras, e dá outras providências. Diário Oficial da União, 16 ago. 1968. Recuperado de http://www2.camara.leg.br/legin/ fed/decret/1960-1969/decreto-63104-15-agosto-1968-404277-publicacaooriginal-1-pe.html

Deleuze, G. (2009). Sacher-masoch: O frio e o cruel. Rio de Janeiro, RJ: Jorge Zahar.

Didi-Huberman, G. (2013). Cascas. Serrote: Uma Revista de Ensaios, Artes Visuais, Ideias e Literatura, (13), 99-133.

Diniz, A. (1998). A evolução da fronteira em Roraima: O caso das confianças I, II e III. In: C. Alves, Formação do espaço amazônico e relações fronteiriças (pp. 150-179). Boa Vista, RR: Universidade Federal de Roraima.

\footnotetext{
${ }^{10}$ Trecho de entrevista proferida por Otávio do Rêgo Barros, porta-voz oficial da Presidência da República, informando a inclusão do Linhão de Tucuruí no escopo das ações essenciais à soberania e integridade nacional pelo Conselho de Defesa Nacional e explicitando a perspectiva a ser adotada pelo Governo Federal em relação ao trato com a comunidade afetada (Mazui, 2019).
} 
Foucault, M. (2012) A vida dos homens infames. In: M. Foucault, Estratégia, poder-saber: Ditos e escritos (Vol. 4, pp. 199-217). Rio de Janeiro, RJ: Forense Universitária.

Freud, S. (2006). O mal-estar na civilização. In: S. Freud, Obras completas vol. XXI: O futuro de uma ilusão, o mal-estar na civilização e outros trabalhos (1927-1931) (pp. 65-68). Rio de Janeiro, RJ: Imago.

Gagnebin, J. M. (2006). Lembrar escrever esquecer. São Paulo, SP: 34.

Instituto Brasileiro de Geografia e Estatística - IBGE. (1970). Censo demográfico: 1970. Rio de Janeiro, RJ: o autor.

Kopenawa, D., \& Albert, B. (2015). A queda do céu: Palavras de um xamã yanomami. São Paulo, SP: Companhia das Letras.

Lemos, F. C., \& Galindo, D. (2013). Massacre e resistência Kaiowá e Guarani: Interrogações às psicologias nos traçados do intolerável. Psicologia: Ciência e Profissão, 33(4), 976-987. https://doi.org/10.1590/S1414-98932013000400015

Mazui, G. (2019, 27 fev.). Construção de linha de energia para Roraima será acelerada, diz porta-voz da Presidência. G1 Roraima. Recuperado de https://g1.globo.com/rr/roraima/noticia/2019/02/27/construcao-de-linha-de-energia-para-roraima-sera-acelerada-diz-porta-voz-da-presidencia.ghtml

Mbembe, A. (2016). Necropolítica. Arte \& Ensaios, (32), 123-151.

Medida provisória No 870, de 1 de janeiro 2019. Estabelece a organização básica dos órgãos da Presidência da República e dos Ministérios. Diário Oficial da União, 3 jan. 2019. Recuperado de http://www.planalto.gov.br/ ccivil_03/_Ato2019-2022/2019/Mpv/mpv870.htm

Resolução No 1, de 27 de fevereiro de 2019. Diário Oficial da União, 28 fev. 2019. Recuperado de http://pesquisa. in.gov.br/imprensa/jsp/visualiza/index.jsp?data=28/02/2019\&jornal=600\&pagina $=1$

Sabatini, S. (1998). Massacre. Brasília, DF: Conselho Indigenísta Missionário.

Schwade, E. (2011). 2000 Waimiri-atroari desaparecidos durante a Ditadura Militar. Brasília, DF: Conselho Indígena Missionário. Recuperado de https://www.cimi.org.br/2011/05/32102/

$6^{\circ}$ BEC se orgulha de ter contribuído para desenvolvimento de Roraima (2016, 28 jul.). Folha de Boa Vista. Recuperado de https://folhabv.com.br/noticia/6o-BEC-se-orgulha-de-ter-contribuido-para-desenvolvimento-de-Roraima/ 18632

Souza, S., \& Vieira, J. (2009). Roraima: Território federal sob o governo militar (1964 a 1985). Textos \& Debates, (19), 65-89. https://doi.org/10.18227/2217-1448ted.v2i17.737

\section{Lazaro Batista}

Docente do curso de Psicologia da Universidade Federal de Roraima (UFRR), Boa Vista - RR. Brasil. Doutorando em Psicologia pela Universidade Federal Fluminense (UFF), Niterói - RJ. Brasil. Mestre em Psicologia Social e Política pela Universidade Federal de Sergipe (UFS), São Cristóvão - SE. Brasil.

E-mail: lazaro.batista@ufrr.br

http://orcid.org/0000-0002-3224-411X

\section{Luis Antonio dos Santos Baptista}

Professor Titular do Instituto de Psicologia da UFF, Doutor em Psicologia urbana na Universidade de Roma, Pesquisador do CNPQ.

E-mail: baptista509@gmail.com

http://orcid.org/0000-0002-5693-0747

\section{Leonardo de Nardin}

Acadêmico do curso de História pela Universidade Federal de Roraima.

E-mail: leodenardin96@gmail.com

http://orcid.org/0000-0003-2866-8718 
Endereço para envio de correspondência:

Universidade Federal de Roraima, Avenida Ene Garcez, 2413,

CEDUC/Psicologia, bl. 02, sala 03.

Recebido 23/03/2019

Aceito 06/05/2019

Received 03/23/2019

Approved 05/06/2019

Recibido 23/03/2019

Aceptado 06/05/2019

Como citar: Batista, L., Baptista, L. A S., \& de Nardin, L. (2019). Peles e vidas transformadas em asfalto: Inquirições ético-políticas de uma barbárie. Psicologia: Ciência e Profissão, 39(n.spe), 101-112. https://doi.org/10.1590/1982-3703003221676

How to cite: Batista, L., Baptista, L. A S., \& de Nardin, L. (2019). Skins and lives turned into asphalt: Ethical-political inquiries of barbarism. Psicologia: Ciência e Profissão, 39(n.spe), 101-112. https://doi.org/10.1590/1982-3703003221676

Cómo citar: Batista, L., Baptista, L. A S., \& de Nardin, L. (2019). Pieles y vidas transformadas en asfalto: Indagaciones ético-políticas de una barbarie. Psicologia: Ciência e Profissão, 39(n.spe), 101-112. https://doi.org/10.1590/1982-3703003221676 